\title{
Study Effects of Planting Methods and Tank Mixed Herbiciedes on Weeds Controlling and Wheat Yield
}

\author{
Zoheir.Y.Ashrafi (Corresponding author) \\ Department of Weed Science, Faculty of Agronomy and Animal Science \\ University College of Agricultural and Natural Resource \\ University of Tehran and Teacher at Payame Noor University (PNU), Tehran State, Iran \\ Tel: 98-261-280-1011 E-mail: z.y.ashrafi@gmail.com \\ Hamid.R.Mashhadi \\ Department of Weed Science, Faculty of Agronomy and Animal Science \\ University College of Agricultural and Natural Resource, University of Tehran, Iran \\ Sedigheh sadeghi \\ Department of Weed Science, Faculty of Agronomy and Animal Science \\ University College of Agricultural and Natural Resource \\ University of Tehran and Teacher at Payame Noor University, Tehran State, Iran \\ Tel: 98-912-528-8240 E-mail:ssadeghi@ut.ac.ir \\ Robert E. Blackshaw \\ Research Scientist - Weed Science Agriculture and Agri-Food Canada \\ Research Centre, blackshaw@agr.gc.ca
}

The research is financed by University of Tehran (Sponsoring information)

\begin{abstract}
The aim of integrated weed management (IWM) is to use of a combination of different practices to maintain weed densities at manageable levels. A field experiment was conducted at Agricultural College, Tehran of University, in Karaj city 2005-2006 by planting wheat, to investigate the response of planting methods and tank mixed herbicides. The experiment was laid out using a split plot arrangement, in randomized complete block design with three replications. Methods of planting were assigned to the main plots; while tank mixed herbicdes were kept in the sub-plots. The subplot size measured $4.5 \times 4.5 \mathrm{~m}^{2}$. Row to row distance was kept at $30 \mathrm{~cm}$. Data were recorded on weed density $\mathrm{m}^{-2}$, plant height $(\mathrm{cm})$, spike length $(\mathrm{cm})$, Number of spikes $\mathrm{m}^{-2}$, Number of grains spike $\mathrm{e}^{-1}, 1000$ grain weight $(\mathrm{g})$, biological yield $\left(\mathrm{kg} \mathrm{ha}^{-1}\right)$, and grain yield $\left(\mathrm{kg} \mathrm{ha}^{-1}\right)$. The data for individual traits were subjected to the ANOVA technique and significant means were separated by the LSD test. The analysis of the data showed that methods of sowing were statistically significant for plant height, No. of grains spike $e^{-1}, 1000$-grain weight and biological yield. The herbicides were statistically significant for all the parameters investigated except No. of grains spike ${ }^{-1}$, while the interaction of methods of planting with herbicides could not reach the level of significance in any of the traits examined. Among the methods of planting, line sowing was the best followed by line + broadcast sowing. The herbicide mixtures controlled mixed stands of broadleaf and grassy weeds to the tune of 65 to $74 \%$ with a consequent increase in grain yield from 58107\%. Buctril-M + Topik 15 WP, 2,4-D + Puma Super 75 EW and Topik 15 WP were segregated as the top scoring applications by increasing yield to the extent of 107,104 and $101 \%$, respectively over the weedy check.
\end{abstract}


Keywords: Planting, Mix- herbicides, Wheat, Weed control, Grain yield

\section{Introduction}

Herbicides have increasingly become a key component of weed management programs in developed countries, one being the reason accounts for increased crop yields in these countries. Nearly $61 \%$ of total herbicides used worldwide were applied in North America and Europe in 2004, with 15\% in Asian countries (Anonymous 2004). Arable lands of Iran received a total amount of 11.1 tons/ha herbicides in 2006, over 5.5 tons/ha being applied in wheat farms (Personal comm. Crop Protection Organization, Iran). Wheat (Triticum aestivium L.) belongs to the family Poaceae and is an annual self-pollinated, photoperiodically long day grass. Like other grasses wheat produces tillers depending upon soil fertility and micro- and macro-environment. Wheat is the most important staple food crop for the whole world. Its cultivation is simple and adaptable to a varied soil and climatic conditions. It is also known as the king of cereals. Besides food, wheat is used for livestock and poultry feeds. A large population of the world consumes wheat in a number of ways. Wheat culture both in Tehran State, as well as in the whole country is the backbone of the whole agricultural system. In Iran, wheat was grown on an area of 4.76 million hectares with a grain production of 14.07 million tons, during 2004-2005. The mean country and provincial productions are limited to $3150 \mathrm{~kg}$ and $1564 \mathrm{~kg}$ ha-1, respectively (.Anonymous, 2004; Baghestani et al , 2005).

During the recent years wheat production has exceeded the requirement of the nation and subsequently the nation has entered into the international wheat export trade. The factors responsible for luxuriant growth and production probably have been the timely availability of fertilizers, higher support prices of wheat and accelerated use of herbicides like Puma super and Topic by the growers. The tempo however, needs to be sustained rather further accelerated, as still there exists a gap between the actual and potential yield of the crop at the farmers' fields. There are several reasons for this gap but the worst one is weed competition with the wheat crop in the field. The weeds use the soil fertility, available moisture, solar radiation and space with crop plants and result in yield reduction. Moreover, the wheat grains contaminated with weed seeds fetch lower prices. As, the nation has entered the international export market, the production of cleaner wheat grains is essential for competition in the international trade. Pervaiz and Quazi (1992) have reported nearly $17.25 \%$ losses caused to the wheat crop by weeds. The losses on annual basis amount to more than Rs. 28 billion at the national level and Rs. 2.00 billion in Iran center (Hassan and Marwat, 2001). Simillary the efficiency of feonaxprop in controlling Sorghum halepens L. (johnsongrass) decreased when mixed with 2,4-D or MCPA (Mueller et al. 1989).

The weeds competitive with wheat crop in Tehran State include Avena fatua, Phalaris minor, Anagallis avensis, Poa annua, Cirsium arvense, Convolvulus arvensis, Ammi visnaga, Chenopodium album, Fumaria polymorpha, Carthamus oxycantha, Euphorbia helioscopia, Medicago denticulata, Melilotus indica, Silybum marianum, Galium aparine and Rumex crispus. Wheat can be sown by different methods viz., drilling in lines, cross sowing or broadcasting. Each method of planting has a varying impact on weed competition. For wheat cultivation the best method is line and line + broadcast sowing (Gogoi and Kalita, 1995; Code and Donaldson, 1996), because of equidistant spacing of wheat, the wheat is better competitive with weeds. Weed control has been practiced since the time immemorial by manual labour (weeding) or animal drawn implements, but these practices were laborious, tiresome and expensive due to increasing cost of labour. The growing mechanization of farm operations and ever increasing labour wages have stimulated interest in the use of chemical weed control. Chemical weed control is the easiest and most successful alternative method. Although different reports are available on the efficacy of different herbicides in wheat (Ashrafi 2006, Baghestani et al, 2005; Mohibullah and Ali , 1974; Gill and Walia, 1979; Praczyk, et al. 1995; Balyan et al., 1983; Porwal and Gupta (1987); Azad et al. 1997; Khan et al., 1999; Khan et al., 2001; Khan et al., 2002; Hashim et al., 2002; Qureshi et al. 2002; Zand et al. 2007), the herbicide use in Iran is not widely practiced as in the agriculturally advanced nations. The interest around the testing of graminicides (Walia et al., 1998; Ormeno and Diaz, 1998; Brar et al., 1999a; Brar et al. $1999 b$ ) indicates the problems posed by grasses. Tank mixing of herbicides is practiced for attaining synergism but, antagonism is also not uncommon in such a mixing (Ashrafi 2006, Williams, 1984; Deschamps, et al., 1990; AugeroAlverdo and Appleby, 1991; Augero-Alverdo, et al., 1991; Pandey and Singh, 1994; Brar et al., 1999b). Whereas, the studies of Panwar et al. (1996) and Khan et al. (2002) showed synergistic response on combined use of herbicides. Tribenuron, 2,4-D + MCPA and bromoxynil have been widely used for broad-leaved weeds control (Zand et al. 2007).

The instant studies were undertaken to evaluate the efficacy of different herbicides alone and in mixture on dynamics of weeds in wheat planted with different methods with these objectives a) to find out the most economical tank mixture of herbicides for the control of weeds in wheat crop b) to figure out the most suitable planting method for wheat cultivation and c) to evaluate the response of wheat to different planting methods and tank mixture of herbicides.

\section{Methods and materials}

A field experiment was conducted at Agricultural College, Tehran of University, in Karaj city 2005-2006 to investigate the efficacy of some herbicide mixtures on grassy and broadleaf weeds and their consequent effect on wheat crop. The experiment was laid out in a split plot design with three replications. In a well-prepared soil, the basal dose of NPK was 
applied. All the phosphorous and potash were applied at the time of planting while, nitrogen was applied in two split doses. First half with the first irrigation and the remaining half at the early boot leaf stage. Methods of sowing (broadcast, line sowing and line + Broadcast) were assigned to the main plots, while ten herbicides detailed below (Table-1) were kept in the subplots. Each sub-plot size measured $4.5 \times 1.5 \mathrm{~m}^{2}$. Row to row distance was kept at $30 \mathrm{~cm}$. Wheat variety Zarrin was sown on the $11^{\text {th }}$ November, 2005 at the rate of $100 \mathrm{~kg} \mathrm{ha}^{-1}$ with broad cost and seed drill and broadcast + drill. The herbicides were applied with a knapsack sprayer during mid-January 2006, after first irrigation, when the soil was in an adequate moisture status. To spray the herbicides successfully all the precautionary measures were adopted so as to avoid any danger of physical exposure to the herbicides. During the course of studies the data were recorded on Weed Density $\left(\mathrm{m}^{-2}\right)$, Plant height $(\mathrm{cm})$, Spike Length $(\mathrm{cm})$, No. of Spikes $\mathrm{m}^{-2}$, No. of Grains spike ${ }^{-1}$, 1000 grain weight $(\mathrm{g})$, Biological yield $\left(\mathrm{kg} \mathrm{ha}^{-1}\right)$ and Grain yield $\left(\mathrm{kg} \mathrm{ha}^{-1}\right)$. Standard procedures were adopted for recording the data on all above traits.

The data recorded for each trait were individually subjected to the ANOVA technique by using SAS Computer software and means were separated by using Fisher's protected LSD test. (1997).

\section{Results and discussion}

An experiment comprising method of sowing and herbicides on wheat was carried out at Agricultural Research, Tehran of University, Karaj city. Data were recorded on weed dynamics and some morphological and agronomic traits of wheat. The data are presented as under:

\subsection{Weed density $m^{-2}$}

The analysis of variance showed that method of planting and interactions of method of planting with herbicides were non-significant statistically while, the herbicidal applications were evaluated as significant statistically. It is evident from the data in Table- 2 that almost similar weed density $\mathrm{m}^{-2}$ was recorded in all methods of planting. However, the highest weed density was recorded in the broadcast sowing (37.2) as compared to line (31.5) or line + broadcast sowing (31.7). All herbicidal combinations although were non-significant among themselves, had a lower density of weeds $\mathrm{m}^{-2}$ as compared to the weedy check (88.889). Among the herbicides numerically lowest weeds (23.4) were recorded in Buctri-M + Isoproturon. The interaction of the method of planting with herbicides was non-significant statistically. However, the lowest weed density (20.1) was observed in line sowing treated with Buctril-M + Topik. The treatments involving line sowing in general, had the lowest infestation as compared to the interactions in line + broadcast or broadcast sowing. The highest weed density (102.69) was recorded in the weedy check under broadcast sowing (Table2). These results are in conformity with Panwar et al, 1995, Pandey and Singh, 1994, Kha et al. (1999), Khan et al. (2002) and Khan et al. (2003) who reported that application of the tank mixed herbicides reduced broad and narrow leaf weeds to a varying degree sometimes approaching $100 \%$. Our findings are however, contrary to the work reported by Ashrafi, 2006, Williams, 1984, Deschamps, et al., 1990, Augero-Alverdo and Appleby, 1991, and Augero-Alverdo, et al., 1991. The variability in findings could be attributed to the different herbicidal combinations tested by those researchers.

\subsection{Plant height $(\mathrm{cm})$}

The analysis of variance showed that method of planting and herbicidal applications were statistically significant, while the interaction between method of planting and herbicides was evaluated as non significant statistically. The perusal of data in Table-3 exhibits that Line + Broadcast and Broadcast Sowing were statistically at par with each other, but surpassed the Line Sowing. More plant height $(102 \mathrm{~cm}$ each) was recorded in Line + Broadcast and Broadcast Sowings. All herbicides although non-significant among themselves had a more plant height as compared to the weedy check (78 $\mathrm{cm})$. Almost all the herbicides gave the equal plant height $(103 \mathrm{~cm})$ numerically except Logran Extra + Topik and Logran Extra + Isoprturon (102 cm), which had slightly lower plant height. Earlier workers like Ahmed et al, 1999 have also found that herbicides do not effect plant height and concluded that trait under reference is strictly under genetic control. The difference in findings can be attributed to the different genetic material used and a variance in environmental conditions. The interaction of method of planting with herbicides although non-significant statistically exhibits that the plant height of the treatments involving Broadcast Sowing was generally taller $(105 \mathrm{~cm})$ than the other planting methods. The minimum plant height $(75 \mathrm{~cm})$ was observed in the weedy check under the Line sowing (Table3). These results are corroborated with the conclusions of Gogoi and Kalita, 1995.

\subsection{Spike length ( $\mathrm{cm})$}

The analysis of variance showed that methods of sowing and interaction of method of planting with herbicides were statistically non significant, while the herbicidal applications were detected as significant. It is evident from the data in Table -4 that almost similar spike length was recorded in all methods of planting. However, the longest spikes $(10 \mathrm{~cm})$ were recorded in Line and Line + Broadcast sowing. All tank mixed herbicides although non significant among themselves had a more spike length $(10 \mathrm{~cm})$ as compared to the weedy check $(9 \mathrm{~cm})$. The interaction of method of planting with herbicides was non-significant statistically, yet the highest spike length $(11 \mathrm{~cm})$ was observed in Line + 
Broadcast Sowing treated with 2, 4-D + Puma Super, 2, 4-D + Topik, Logran Extra + Puma Super, Logran Extra + Topik and in Broadcast 2, 4-D + Puma Super (Table-4). These results are in agreement with the work of Ahmed et al, 1999, who reported that spike length is significantly affected by herbicidal applications.

\subsection{No. of spikes $m^{-2}$}

The No. of spikes per unit area is the most important trait contributing to the grain yield in wheat. The data on No. of spikes per $\mathrm{m}^{2}$ are presented in (Table-5). The statistical analysis of the data indicated that methods of sowing and interaction of method of sowing with herbicides was statistically non significant while, the differences among the herbicides were detected as significant. The data in Table-5 show that almost similar spikes $\mathrm{m}^{-2}$ were recorded in all methods of sowing. However, the highest spikes $\mathrm{m}^{-2}$ (276.47) were observed in line sowing as compared to Line + Broadcast (269.53) or Broadcast (246.73) sowing. Among the herbicides the highest No. of spikes $\mathrm{m}^{-2}$ were recorded in 2, 4-D + Topik (276.67) which however were statistically at par with all other herbicidal applications but statistically higher than the weedy check (199.78) [Table -5]. The interaction of the method of planting with the herbicides although non-significant statistically exhibited that the spikes $\mathrm{m}^{-2}$ of the treatments involving Line sowing were generally higher than the other planting methods. Line sowing treated with Buctril-M+Topik (293.00) gave the maximum No. of spikes $\mathrm{m}^{-2}$ (Table-5) .

\subsection{Number of grains spike ${ }^{-1}$}

Number of grains spike ${ }^{-1}$ is another important component of yield. Change in number of grains spike ${ }^{-1}$ drastically influences the final yield. The analysis of data showed that the variable method of sowing was evaluated as significant, while the herbicides and interaction of methods of planting with herbicides were statistically non significant. The data in Table-6 exhibits those higher grains spike ${ }^{-1}$ (53.213) were recorded in line sowing. However, it was statistically at par with line + broadcast sowing (50.197) but higher than broadcast sowing (44.2). The herbicidal treatments were statistically non significant, but numerically the highest No. of grains (52.41) were observed in 2,4-D + Topik. Minimum grains (45.00) were recorded in weedy check (Table 6). The interaction of method of planting with herbicides although non significant statistically, exhibited higher grains spike ${ }^{-1}$ (59.569) in the line sowing treated with 2 , 4D+Topik. The lowest grains spike ${ }^{-1}$ (42.333) were recorded in the 2,4-D+Isoproturon under the broadcast planted treatment. These results are corroborated with the results of Balyan et al., 1983, Khan et al, 2001, Khan et al., 2002 and Khan et al, 2003, who concluded that herbicidal applications produce more grains spike ${ }^{-1}$ than the untreated control.

\subsection{0-grain weight $(g)$}

The analysis of data indicated that the methods of planting and herbicides were significant statistically, while the interaction of method of planting with herbicides was statistically non significant. The maximum1000 grain weight (39 g) was recorded in line + broadcast sowing, but it was statistically higher than the line and broadcast sowing (37 g) [Table 7]. Among the herbicides, the maximum 1000 grain weight was recorded in Buctril-M+Topik and Logran Extra+ Puma Super (39 g) each which however were statistically at par with all other herbicidal applications, but statistically higher than the weedy check $(30 \mathrm{~g})$. The interaction of method of planting with herbicides although non significant statistically, showed that the treatments involving line and line + broadcast sowing generally had bolder grain than broadcast sowing. Line sowing treated with Buctril-M+Puma Super (40 g each) had the highest 1000 grains weight (Table -7), while broadcast and line sowings under the weedy check (28 $\mathrm{g}$ each) possessed the smallest kernel size. Similar results were also reported by Tanveer et al., 1999, Balyan et al., 1996 and Samunder et al., 1994, who concluded that the herbicides were very effective for weed control and also gave best crop yield.

\subsection{Biological yield $\left(\mathrm{kg} \mathrm{ha}^{-1}\right)$}

The analysis of variance showed that method of planting and herbicidal applications were statistically significant, while the interaction of method of planting with herbicides was recorded as statistically non significant. The highest biological yield (17763 $\left.\mathrm{kg} \mathrm{ha}^{-1}\right)$ was recorded in Line sowing, while Line +Broadcast (16739) and Broadcast sowing (15970) were statistically at par with each other (Table -8). Among the herbicides, the highest biological yield $\left(18793 \mathrm{~kg}^{-1}\right) \mathrm{was}^{-}$ recorded in 2, 4-D + Puma Super. However, it was statistically at par with all other herbicidal applications except Logran Extra + Topik (15638 kg ha $\left.{ }^{-1}\right)$. The lowest biological yield $\left(10908 \mathrm{~kg} \mathrm{ha}^{-1}\right)$ was observed in the weedy check. The interaction of method of planting with herbicides although non-significant statistically exhibits that the biological yield of the treatments involving Line sowing was generally higher than the other planting methods. Line sowing treated with 2,4-D + Puma super gave maximum biological yield $\left(23241 \mathrm{~kg} \mathrm{ha}^{-1}\right)$ than rest of the interactions. The minimum biological yield $\left(10601 \mathrm{~kg} \mathrm{ha}^{-1}\right)$ was recorded in weedy check under the Line + broadcast sowing. The herbicide 2,4-D + Puma super gave the excellent control of weeds hence consequently it increased the biological yield (Table-8 ). These results are in a greater agreements with the work of Porwal and Gupta, 1987 and Brar et al., $1999 \mathrm{~b}$. They also reported that different herbicides reduced weed and increased grain and straw yield of wheat over the control plots. 


\subsection{Grain yield $\left(\mathrm{kg} \mathrm{ha}^{-1}\right)$}

The data showed that method of sowing and the interaction of method of sowing with herbicides were statistically nonsignificant while, the differences among the herbicides were detected as significant. The perusal of data (Table 9) exhibited that almost similar grain yield was recorded in all methods of planting. However, the line + broadcast had a slightly higher yield (4142.78 $\mathrm{kg} \mathrm{ha}^{-1}$ ) as compared to line (4078.39) or broadcast sowing (4088.53). All the herbicides out yielded the weedy check. Among the herbicides the highest yield was recorded in Buctril-M + Topik (4771.06 kg $\left.\mathrm{ha}^{-1}\right)$. However, it was statistically at par with all other herbicidal applications except Buctril-M + Isoprutron (3631.82 $\left.\mathrm{kg} \mathrm{ha}^{-1}\right), 2,4-\mathrm{D}+$ Isoprturon (3775.64 $\mathrm{kg} \mathrm{ha}^{-1}$ ), and Buctril-M + Puma Super (4138.53 kg ha ${ }^{-1}$ ). The herbicide Buctril-M + Isoprotran was in turn statistically comparable with Buctril-M + Puma Super (4138.53 kg ha $\left.{ }^{-1}\right)$, Logran Extra + Topik $\left(4378.86 \mathrm{~kg} \mathrm{ha}^{-1}\right.$ ), Logran Extra + Isoprutron (4389.79 $\mathrm{kg} \mathrm{ha}^{-1}$ ) and Logran+Puma Super (4314.13 $\mathrm{kg} \mathrm{ha}^{-1}$ ) (Table 9). The herbicides Buctril-M+Topik gave an excellent control of weeds hence consequently increased the grain yield. The interaction of the method of planting with the herbicides although non-significant statistically exhibited that the yield of treatments involving line+broadcast sowing was generally higher than the planting with the other methods. Line+Broadcast treated with 24-D+Puma Super out yielded $\left(5115.23 \mathrm{~kg} \mathrm{ha}^{-1}\right)$ the rest of the interactions. The lowest grain yield $\left(2239.68 \mathrm{~kg} \mathrm{ha}^{-1}\right)$ was recorded in the weedy cheek, under line sowing. These findings are in a close conformity with Pandey and Singh 1994, Azad et al, 1997, and Samunder et al, 1994 who reported a differential response of various herbicides on the grain yield of wheat.

\section{References}

Anonymus, (2006). Crop Protection Handbook. Biesterfield.

Anonymous. (2004). Agricultural Statistics of Iran. Ministry of Food Agriculture and Livestock, Government of Iran. Tehran

Ashrafi, Z. Y. (2006). Effect of tankmix herbicide and fertilizer on wheat yield and weed control, M. S.c thesis, Agriculture College, University Of Tehran., Iran.

Augero-Alverdo, R. and A.P. Appleby. (1991). Uptake, translocation, and phytotoxicity of root-absorbed haloxyfop in soybeans, Festuca rubra L., Festuca arundinacea Schreb. Weed Res. 31:257-263.

Augero-Alverdo, R., A.P. Appleby and D.J. Armstrong. (1991). Antagonism of haloxyfop activity in tall fescue (Festuca arundinacea) by dicamba and bentazon. Weed Sci. 39:1-5.

Azad, B.S., S. Harbans and H. Singh. (1997). Effect of time, methods of application of herbicide and nitrogen on weed_control in wheat. Annals Agric. Res. 18 (2): 174-177.

Balyan, R.S., V.M. Bhan and S.P. Singh. (1983). Evaluation of herbicides in wheat. Indian J. Weed Sci. 15(1): 43-46.

Balyan, R.S. and R.K. Malik. (1996). Effect of spray volume on herbicide efficacy in wheat (Triticum aestivum L.). Haryana Agric. Univ. J. Res. 26 (4): 249-257.

Baghestani, M.A., Zand, E., Soufizadeh, S., Mirvakili, M., Jaafarzadeh, N., 2007. Response of winter wheat (Triticum aestivum L.) and weeds to tank mixture of 2,4-D plus MCPA with clodinafop propargyl. Crop Prot. in press.

Brar L.S., U.S. Walia and B.K. Dhaliwal. (1999a). Bioefficacy of new herbicide for the control of resistant Phalaris minor in wheat. Pesti. Res. J. 11(2): 177-180.

Brar, L.S., U.S. Walia and B.K. Dhaliwal. (1999b). Performance of clodinafop for the control of wild oat (Avena ludoviciana) in wheat. J. Res. Punjab Agric. Univ., 36(3-4):187-190.

Carlson, H.L. (1986). Wild oat competition with spring wheat. Dissert. Absts. 5(2): 1180.

Code, G. R. and T.W. Donaldson. (1996). Effect of cultivation, sowing methods and herbicides on wild radish populations in wheat crops. Aust. J. Exper. Agric. 36 (4): 437-442.

Deschamps, R.J.A., A.I. Hsio and W.A. Quick. (1990). Antagonistic effect of MCPA on Fenoxaprop activity. Weed Sci. 38:62-66.

Gill, H.S. and U.S. Walia. (1979). Herbicidal control of Phalaris minor Retz. in wheat. Proc. 7th Conf. of the AsianPacific Weed Sci. Soc., pp. 9-62. [Weed Absts., 30(7):2251;1981] .

Gogoi, A.K. and H. Kalita. (1995). Effect of seeding method and herbicides on weeds and growth and yield of wheat (Triticum aestivum). Indian J. Agron. 40 (2): 209-211.

Hashim, S., K.B. Marwat and G. Hassan. (2002). Response of wheat varieties to substituted herbicides. Pak. $J$. Weed_Sci. Res. 8 (1-2):49-56. 
Hassan, G. and K.B. Marwat. (2001). Integrated Weed Management in agricultural crops. Proc. National Workshop on technologies for Sustainable Agriculture, Sep. 24-26, 2001, NIAB, Faisalabad, Pakistan, pp. 27-34 (ISBN 969-8038-094).

Khan, I., Z. Muhammad, G. Hassan and K.B. Marwat. (2001). Efficacy of different herbicides for controlling weeds in wheat crop-1. Response of agronomic and morphological traits in wheat variety Ghaznavi-98. Scientific Khyber 14(1):51-57.

Khan, I., G. Hassan and K.B. Marwat. (2002). Efficacy of different herbicides for controlling weeds in wheat crop-II. Weed dynamics and herbicides. Pak. J. Weed Sci. Res. 8(1-2): 41-47.

Khan, N., G. Hassan, K.B. Marwat and M.A. Khan. (2003). Efficacy of different herbicides for controlling weeds in wheat crop at different times of application - II. Asian J. Plant Sci. 2(3): 310-313.

Mohibullah and A. Ali. 1974. Efficacy of different herbicides in controlling weeds and their effect on wheat yield. Front. J. Agric. Res. 1(1): 41-45.

Mueller, T.C., Witt, W.W., Barrett, M., 1989. Antagonism of johnsongrass (Sorghum halepense) control with fenoxaprop, haloxyfop, and sethoxydim by 2,4-D. Weed Technol. 3, 86-89.

Ormeno, N.J. and S.J. Diaz. (1998). I Clodinafop, a new herbicide for the selective control of grassy weeds in wheat. II Selectivity on spring and alternative cultivars. Agricultura, Tecnica, Santiago 58(2): 103-115.

Pandey, J. and R. P. Singh. (1994). Effect of sulfonyl urea herbicides on weed control in wheat (Triticum aestivum). Indian J. Agron. 39 (4):565-568.

Panwar, R.S., R.K. Malik and S.S. Rathi. (1996). Effect of tralkoxydim and its combination with other new herbicides on the control of weeds in wheat. Indian J. Agron. 41 (3): 401-405.

Porwal, M.K. and O.P. Gupta. (1987). Studies on chemical control in wheat. Indian J. Agron. 32(3): $282-283$.

Praczyk, T., K. Adamczewski, K. Miklaszewska and J. Gorniak. (1995). Estimation of Logran Extra 62 WG for weed_control in wheat. Materialy, Sesji, Instytutu, Ochrony, Roslin 35(2): 311-313.

Qureshi, M.A., A.D. Jarwar, S.D. Tunio and H.I. Majeedano. (2002). Efficacy of various weed management practices_in_wheat.Pak.J.Weed Sci.Res. 8(1-2): 63-69.

Samunder, S., R.K. Malik and S. Singh. (1994). Effect of 2,4-D and tribenuron on the control of broad-leaf weeds in wheat (Triticum aestivum). Indian J. Agron. 39(3): 410-414.

SAS Institute. (1997). SAS User's Guide: Statistic. SAS Institute, Cary, NC.

Steel, R.G.D. and J.H. Torrie. (1980). Principles and procedures of statistics a biological yield approach, $2^{\text {nd }}$ ed._McGraw Hill Book Co., Inc. New York.

Walia, U.S., L.S. Brar and B.K. Dhaliwal. (1998). Performance of Clodinafop and Fenaxapro-p-ethyl for the control of Phalaris minor in wheat. Indian J. Weed Sci. 30: (1-2): 48-50.

Williams, C.S. (1984). Interaction of bentazon with haloxyfop-methyl or sethoxydim. Ph.D Dissert. Agron. Deptt. University of Illinois, Urbana, IL., USA.

Zand E., Baghestani, M.A., Bitarfan, M., Shimi, P., 2007. Analysis of herbicides management in Iran. Jihad-eAgriculture Press. 41pp.

Zand E., Baghestani, M.A., Soufizadeh, S., PourAzar, R., Veysi, M., Bagherani, N., Barjasteh, A., Khayami, M.M., Nezamabadi, N., 2006. Broadleaved weed control in winter wheat (Triticum aestivum L.) with post-emergence herbicides in Iran. Crop Prot. in press. 
Table 1. Detail of the tank mixed herbicides assigned to the sub-plots

\begin{tabular}{|c|c|c|c|}
\hline S. No. & Herbicides Mixtures (Trade name) & Common Name & $\begin{array}{l}\text { Dose (kg a.i.ha } \\
\text { 1) }\end{array}$ \\
\hline .1 & 2,4-D+ Puma Super 75 EW & 2,4-D fecnoxaprop-p-ethyl & $0.90+0.84$ \\
\hline .2 & 2,4-D + Topik 15 WP & $2,4-\mathrm{D}+$ clodinafop & $0.90+0.04$ \\
\hline .3 & 2,4-D + Isoproturan $50 \mathrm{WP}$ & $2,4-\mathrm{D}+$ isoproturon & $0.90+0.63$ \\
\hline .4 & Buctril-M40 EC+Puma Super 75 EW & $\begin{array}{l}\text { (bromoxynil }+ \text { MCPA) }+ \\
\text { fenoxaprop-p-ethyl }\end{array}$ & $0.70+0.94$ \\
\hline .5 & Buctril-M 40 EC + Topik 15 WP & $\begin{array}{l}\text { (bromoxynil }+\mathrm{MCPA})+ \\
\text { isoproturon }\end{array}$ & $0.70+0.14$ \\
\hline .6 & Buctril-M 40 EC +Isoproturon $50 \mathrm{WP}$ & $\begin{array}{l}(\text { bromoxynil }+\mathrm{MCPA})+ \\
\text { isoproturon }\end{array}$ & $0.71+0.63$ \\
\hline .7 & Logran Extra 64 WG + Puma Super 75 EW & $\begin{array}{l}\text { (triasulfuron+ terbutryn)+ } \\
\text { fenoxaprop-p-ethyl }\end{array}$ & $0.16+0.94$ \\
\hline .8 & Logran Extra 64 WG + Topik 15 WP & $\begin{array}{ll}\text { (triasulfuron }+ & \text { terbutryn) }+ \\
\text { clodinafop } & \end{array}$ & $0.16+0.04$ \\
\hline .9 & Logran Extra $64 \mathrm{WG}+$ Isoproturon $50 \mathrm{WP}$ & $\begin{array}{l}\text { (triasulfuron }+ \text { terbutryn)+ } \\
\text { isoproturon }\end{array}$ & $0.16+0.63$ \\
\hline 10 & Weedy check (no weeding) & - & - \\
\hline
\end{tabular}

Table 2. Effect of method of planting and herbicides on weed density $\left(\mathrm{m}^{-2}\right)$ in Wheat

\begin{tabular}{|l|l|l|l|l|}
\hline Herbicidal combination & Line sowing & $\begin{array}{l}\text { Line } \\
\text { Broadcast }\end{array}$ & Broadcast & $\begin{array}{l}\text { Herbicide } \\
\text { Means }\end{array}$ \\
\hline 2,4-D + Puma Super & 22.333 & 25.667 & 31.667 & $26.556 \mathrm{~A}^{*}$ \\
\hline 2,4-D + Topic & 26.000 & 24.667 & 31.000 & $27.224 \mathrm{~A}$ \\
\hline 2,4-D + Isoproturon & 27.000 & 28.333 & 34.667 & $30.000 \mathrm{~A}$ \\
\hline Buctril-M+ Puma Super & 29.000 & 30.000 & 34.333 & $31.111 \mathrm{~A}$ \\
\hline Buctril-M+ Topik & 20.000 & 24.667 & 29.000 & $24.556 \mathrm{~A}$ \\
\hline Buctril-M+ Isoproturon & 25.667 & 22.333 & 22.000 & $23.333 \mathrm{~A}$ \\
\hline $\begin{array}{l}\text { Logran Extra+ Puma } \\
\text { Super }\end{array}$ & 25.000 & 28.667 & 33.667 & $29.211 \mathrm{~A}$ \\
\hline Logran Extra + Topik & 24.667 & 25.667 & 24.000 & $24.778 \mathrm{~A}$ \\
\hline $\begin{array}{l}\text { Logran Extra }+ \\
\text { Isoproturon }\end{array}$ & 23.000 & 27.000 & 26.000 & $25.333 \mathrm{~A}$ \\
\hline Weedy check & 82.000 & 80.000 & 104.667 & $88.889 \mathrm{~B}$ \\
\hline Mean & 30.467 & 31.700 & 37.100 & \\
\hline
\end{tabular}

$\operatorname{LSD}_{0.05}$ for herbicides $=11.26$

* The means sharing a letter in common do not differ significantly by LSD test at 5\% probability level. 
Table 3. Effect of method of planting and herbicides on plant height $(\mathrm{cm})$ in wheat

\begin{tabular}{|l|l|l|l|l|}
\hline Herbicidal Combination & Line sowing & $\begin{array}{l}\text { Line } \\
\text { Broadcast }\end{array}$ & Broadcast & Mean \\
\hline 2,4-D + Puma Super & 100 & 103 & 105 & $103 \mathrm{~A} *$ \\
\hline 2,4-D + Topic & 101 & 103 & 105 & $103 \mathrm{~A}$ \\
\hline 2,4-D+ Isoproturon & 100 & 104 & 104 & $103 \mathrm{~A}$ \\
\hline Buctril-M+ Puma Super & 100 & 104 & 105 & $103 \mathrm{~A}$ \\
\hline Buctril-M+ Topic & 100 & 104 & 104 & $103 \mathrm{~A}$ \\
\hline Buctril-M+ Isoproturon & 101 & 104 & 104 & $103 \mathrm{~A}$ \\
\hline $\begin{array}{l}\text { Logran Extra Puma } \\
\text { Super }\end{array}$ & 100 & 104 & 104 & $102 \mathrm{~A}$ \\
\hline Logran Extra Topic & 99 & 103 & 103 & $102 \mathrm{~A}$ \\
\hline $\begin{array}{l}\text { Logran Extra } \\
\text { Isoproturon }\end{array}$ & 98 & 104 & 104 & $78 \mathrm{~B}$ \\
\hline Weedy check & 75 & 81 & 79 & $102 \mathrm{~A}$ \\
\hline Mean & 98 & $102 \mathrm{~A}$ & $\mathrm{~A}$ & \\
\hline
\end{tabular}

$\operatorname{LSD}_{0.05}$ for sowing methods $=3.348$, LSD $_{0.05}$ for herbicides $=2.671$, ${ }^{*}$ The means sharing a letter in common in their respective category do not differ significantly by LSD test at $5 \%$ probability level.

Table 4. Effect of method of planting and herbicides on spike length (cm) in wheat

\begin{tabular}{|l|l|l|l|l|}
\hline Herbicidal Combination & Line sowing & $\begin{array}{l}\text { Line } \\
\text { Broadcast }\end{array}$ & Broadcast & Mean \\
\hline 2,4-D + Puma Super & 10 & 11 & 11 & $10 \mathrm{~A}^{*}$ \\
\hline 2,4-D + Topic & 10 & 11 & 9 & $10 \mathrm{~A}$ \\
\hline 2,4-D + Isoproturon & 10 & 10 & 10 & $10 \mathrm{~A}$ \\
\hline Buctril-M+ Puma Super & 10 & 10 & 9 & $10 \mathrm{~A}$ \\
\hline Buctril-M+ Topic & 10 & 10 & 10 & $10 \mathrm{~A}$ \\
\hline Buctril-M+ Isoproturon & 10 & 10 & 10 & $10 \mathrm{~A}$ \\
\hline $\begin{array}{l}\text { Logran Extra + Puma } \\
\text { Super }\end{array}$ & 10 & 11 & 9 & $10 \mathrm{~A}$ \\
\hline Logran Extra Topic & 9 & 11 & 9 & $10 \mathrm{~A}$ \\
\hline $\begin{array}{l}\text { Logran Extra } \\
\text { Isoproturon }\end{array}$ & 9 & 10 & 9 & $10 \mathrm{~A}$ \\
\hline Weedy Check & 9 & 9 & 9 & $9 \mathrm{~B}$ \\
\hline Mean & 10 & 10 & 9 & \\
\hline
\end{tabular}

$\mathrm{LSD}_{0.05}$ for herbicides $=0.9822$, *The means sharing a letter in common do not differ significantly by LSD test at $5 \%$ probability level. 
Table 5. Effect of methods of planting and herbicides on No. of Spikes $\mathrm{m}^{-2}$ in wheat

\begin{tabular}{|l|l|l|l|l|}
\hline Herbicidal Combination & Line sowing & $\begin{array}{l}\text { Line } \\
\text { Broadcast }\end{array}$ & Broadcast & Mean \\
\hline 2,4-D + Puma Super & 275.00 & 277.00 & 233.33 & $261.78 \mathrm{~A}^{*}$ \\
\hline 2,4-D + Topic & 288.67 & 281.67 & 259.67 & $276.67 \mathrm{~A}$ \\
\hline 2,4-D + Isoproturon & 278.33 & 279.33 & 266.67 & $274.78 \mathrm{~A}$ \\
\hline Buctril-M+ Puma Super & 286.00 & 263.00 & 263.00 & $270.67 \mathrm{~A}$ \\
\hline Buctril-M+ Topic & 293.00 & 270.67 & 262.67 & $275.44 \mathrm{~A}$ \\
\hline Buctril-M+ Isoproturon & 280.00 & 276.33 & 272.67 & $276.33 \mathrm{~A}$ \\
\hline $\begin{array}{l}\text { Logran Extra + Puma } \\
\text { Super }\end{array}$ & 289.67 & 283.33 & 237.33 & $270.11 \mathrm{~A}$ \\
\hline Logran Extra Topic & 288.00 & 280.67 & 230.33 & $266.33 \mathrm{~A}$ \\
\hline $\begin{array}{l}\text { Logran Extra }+ \\
\text { Isoproturon }\end{array}$ & 280.33 & 275.67 & 255.67 & $270.56 \mathrm{~A}$ \\
\hline Weedy Check & 205.67 & 207.67 & 186.00 & $199.78 \mathrm{~B}$ \\
\hline Mean & 276.47 & 269.53 & 246.73 & \\
\hline
\end{tabular}

$\mathrm{LSD}_{0.05}$ for herbicides $=39.46$, *The means sharing a letter in common do not differ significantly by LSD test at $5 \%$ probability level.

Table 6. Effect of method of planting and herbicides on No. of grains Spike ${ }^{-1}$ in wheat

\begin{tabular}{|l|l|l|l|l|}
\hline Herbicidal Combinations & Line sowing & $\begin{array}{l}\text { Line } \\
\text { Broadcast }\end{array}$ & Broadcast & Mean \\
\hline 2,4-D + Puma Super & 52.100 & 52.00 & 42.667 & 48.92 \\
\hline 2,4-D + Topic & 59.569 & 50.667 & 47.000 & 52.41 \\
\hline 2,4-D + Isoproturon & 50.767 & 50.633 & 42.333 & 47.81 \\
\hline Buctril-M + Puma Super & 54.800 & 49.667 & 48.333 & 50.93 \\
\hline Buctril-M + Topic & 51.433 & 54.133 & 44.333 & 49.97 \\
\hline Buctril-M+ Isoproturon & 54.867 & 50.000 & 43.333 & 49.29 \\
\hline Logran Extra + Puma super & 56.467 & 48.033 & 45.333 & 49.94 \\
\hline Logran Extra + Topic & 57.133 & 51.800 & 43.000 & 50.64 \\
\hline Logran Extra+ Isoproturon & 48.667 & 49.333 & 43.333 & 47.11 \\
\hline Weedy Check & 46.333 & 46.000 & 42.667 & 45.00 \\
\hline Mean & 53.213 A* & $50.197 \mathrm{~A}$ & $44.200 \mathrm{~B}$ & \\
\hline
\end{tabular}

$\mathrm{LSD}_{0.05}$ for sowing methods $=4.618, *$ The means sharing a letter in common do not differ significantly by LSD test at $5 \%$ probability level. 
Table 7. Effect of method of planting and herbicides on 1000 grain weight $(\mathrm{g})$ in wheat

\begin{tabular}{|c|c|c|c|c|}
\hline Herbicidal Combinations & $\begin{array}{l}\text { Line } \\
\text { sowing }\end{array}$ & $\begin{array}{l}\text { Line } \\
\text { Broadcast }\end{array}$ & Broadcast & Mean \\
\hline 2,4-D + Puma Super & 38 & 39 & 38 & $38 \mathrm{~A}^{*}$ \\
\hline 2,4-D + Topic $15 \mathrm{WP}$ & 39 & 39 & 37 & $38 \mathrm{~A}$ \\
\hline 2,4-D + Isoproturon & 38 & 39 & 36 & $38 \mathrm{~A}$ \\
\hline Buctril-M + Puma Super & 40 & 39 & 37 & $38 \mathrm{~A}$ \\
\hline Buctril-M + Topic & 38 & 40 & 38 & $39 \mathrm{~A}$ \\
\hline Buctril-M+ Isoproturon & 39 & 39 & 37 & $38 \mathrm{~A}$ \\
\hline Logran Extra+ Puma Super & 38 & 39 & 39 & $39 \mathrm{~A}$ \\
\hline Logran Extra+Topik 15 WP & 38 & 40 & 37 & $38 \mathrm{~A}$ \\
\hline Logran Extra+ Isoproturon & 37 & 40 & 37 & $38 \mathrm{~A}$ \\
\hline Weedy Check & 28 & 33 & 28 & $30 \mathrm{~B}$ \\
\hline Mean & $37 \mathrm{~B}$ & $39 \mathrm{~A}$ & $37 \mathrm{~B}$ & \\
\hline
\end{tabular}

$\mathrm{LSD}_{0.05}$ for sowing method $=1.62$

$\mathrm{LSD}_{0.05}$ for herbicides $=2.628$

*The means sharing a letter in common in their respective category do not differ significantly by LSD test at $5 \%$ probability level.

Table 8. Effect of method of planting and herbicides on biological yield $\mathrm{kg} \mathrm{ha}^{-1}$ in wheat

\begin{tabular}{|l|l|l|l|l|}
\hline Herbicidal Combinations & Line sowing & $\begin{array}{l}\text { Line } \\
\text { Broadcast }\end{array}$ & Broadcast & Mean \\
\hline 2,4-D + Puma Super & 22222 & 16872 & 17284 & $18793 \mathrm{~A}^{*}$ \\
\hline 2,4-D + Topic 15 WP & 18922 & 18930 & 16173 & $18008 \mathrm{AB}$ \\
\hline 2,4-D + Isoproturon & 19341 & 17284 & 18930 & $18518 \mathrm{AB}$ \\
\hline Buctril-M + Puma Super & 18383 & 17697 & 15638 & $17239 \mathrm{AB}$ \\
\hline Buctril-M + Topic 15 WP & 18107 & 16872 & 15226 & $16735 \mathrm{AB}$ \\
\hline Buctril-M+ Isoproturon & 18930 & 15638 & 18107 & $17558 \mathrm{AB}$ \\
\hline Logran Extra+ Puma Super & 16461 & 16872 & 17284 & $16872 \mathrm{AB}$ \\
\hline Logran Extra + Topic 15 WP & 15638 & 17284 & 13992 & $15638 \mathrm{~B}$ \\
\hline Logran Extra + Isoproturon & 18107 & 19342 & 16461 & $17970 \mathrm{AB}$ \\
\hline Weedy Check & 11523 & 10601 & 10601 & $10908 \mathrm{C}$ \\
\hline Mean & $17763 \mathrm{~A}$ & $16739 \mathrm{~B}$ & $15970 \mathrm{~B}$ & \\
\hline
\end{tabular}

$\mathrm{LSD}_{0.05}$ for sowing methods $=851, \mathrm{LSD}_{0.05}$ for herbicides $=2893,{ }^{*}$ The means sharing a letter in common in their respective category do not differ significantly by LSD test at $5 \%$ probability level. 
Table 9. Effect of method of planting and herbicides on grain yield $\left(\mathrm{kg} \mathrm{ha}^{-1}\right)$ in wheat

\begin{tabular}{|l|l|l|l|l|}
\hline \multirow{2}{*}{ Herbicide Combination } & \multicolumn{4}{l}{ Method of Sowing } \\
\cline { 2 - 5 } & Line sowing & $\begin{array}{l}\text { Line } \\
\text { Broadcast }\end{array}$ & Broadcast & Mean \\
\hline 2,4-D + Puma Super & 4395.06 & 5115.23 & 4568.07 & $4692.78 A^{*}$ \\
\hline 2,4-D + Topic 15 WP & 4802.47 & 4691.36 & 4407.59 & $4633.81 \mathrm{~A}$ \\
\hline 2,4-D + Isoproturon & 3744.86 & 4084.13 & 3497.94 & $3775.64 \mathrm{CD}$ \\
\hline Buctril-M + Puma Super & 3781.89 & 3884.74 & 4748.97 & $4138.53 \mathrm{BC}$ \\
\hline Buctril-M + Topic & 4494.24 & 4979.42 & 4839.51 & $4771.06 \mathrm{~A}$ \\
\hline Buctril-M+ Isoproturon & 3827.16 & 3223.46 & 3844.86 & $3631.82 \mathrm{D}$ \\
\hline Logran Extra + Puma Super & 4979.42 & 3859.67 & 4103.29 & $4314.13 \mathrm{AB}$ \\
\hline Logran Extra + Topic 15 WP & 4320.98 & 4456.57 & 4359.02 & $4378.86 \mathrm{AB}$ \\
\hline Logran Extra + Isoproturon & 4198.19 & 4855.97 & 4115.22 & $4389.79 \mathrm{AB}$ \\
\hline Weedy Check & 2239.68 & 2277.36 & 2400.82 & $2305.76 \mathrm{E}$ \\
\hline Mean & 4078.39 & 4142.78 & 4088.53 & \\
\hline
\end{tabular}

$\mathrm{LSD}_{0.05}$ for treatment $=494.7 *$ The means sharing a letter in common do not differ significantly by LSD test at $5 \%$ probability level. 